Watson, T. (2010). Authenticity and the 'Authentic Enterprise'. Journal of Communication Management, 14 (3), 189-191. http://dx.doi.org/10.1108/jcom.2010.30714caa.003

\title{
Authenticity and The Authentic Enterprise
}

Recently I watched an interview recorded with Tim Traverse-Healey, one of the doyens of public relations in the UK and internationally. Tim was talking about the decade immediately after World War 2, when public relations in this country was getting started in an organised and professional manner. He told my colleague Kevin Moloney about an early visit to New York where he first heard about the "Page Principles" articulated by Arthur Page and the Society that honors him. Tim was mightily impressed at this ethical and professional core to the practice of public relations and carried them forward in his professional life. It is notable that nearly 60 years after first hearing about the "Page Principles", he spoke of them with such high respect.

There is much in these principles to be admired - "Tell the truth; Prove it with action; Listen to the customer; Manage for tomorrow; Realize that a company's true character is expressed by its people; Conduct public relations as if the whole company depends on it; Remain calm, patient and goodhumored” (Page Society 2007, p.17). They must be valued highly, as shown by the strength and importance of the Page Society in the corporate communications life of the USA.

So when one comes to discuss the Page Society report, The Authentic Enterprise, published in 2007, a fundamental question must be whether it has developed the Page Principles into a $21^{\text {st }}$ century model. The report analyses changes that have taken place in the past decade, such as the impact of social media and 24-hour news coverage, the rise of stakeholder activism and of the globalisation of corporations which often now operate in new and unfamiliar cultural settings. Some outcomes of these changes are low levels of trust and credibility for corporations, their CEOs and, especially their PR spokespeople.

Discussion of "authenticity" and concept of the "authentic enterprise” is, however, very limited and contained on just two pages of the report (ibid, pp.15-16) with the sole attempt to define the key term of "authenticity" being text drawn from the American Heritage Dictionary, which is limited to non-conceptual and descriptive factors of which the most relevant is "conforming to fact and therefore worthy of trust, reliance and belief”. There is no attempt to discuss, debate or explore notions and concepts of authenticity, just calls to action such as, "in a word, authenticity will be the coin of the realm for successful corporations and for those who lead them” (ibid, p.6). The report progresses with the use of the term "authentic enterprise" as if the report writers and readers know what is meant. This appears to be based on "do unto others as you would have them do unto you" (Matthew 7:12) or versions of ethics' Golden Rule.

More light comes in the report of an academic symposium held in May 2008 to discuss The Authentic Enterprise, which was organised by the Page Society, the Institute for Public Relations and the Tuck School of Business at Dartmouth. An opening statement in the report, with an eclectic mix 
of tasks, is "the authentic enterprise must define and instill company values, build and manage multistakeholder relationships, enable its [p.190] people with new media skills and tools and actively build and manage trust among its stakeholders” (Academic Symposium 2008, p.2)

The discussion of The Authentic Enterprise then proceeds with four perspectives - business academic, corporate (communicator), agency and communication academic. They review the report and consider the implications for corporate communications practice, especially at senior level.

The business academics took the view that authenticity was a "major metaphor [that] must link all facets of the corporation consistently” (ibid, p.3) but that there was skepticism, post-Enron, about corporations that espouse strong values but fail to perform to them. They, too, referred to the dictionary definition, and concluded that "this [being authentic] involves talking, being and staying authentic - as well as defending the corporation and its reputation in times of trouble” (ibid, p.4).

The corporate communicators' response was that "to be authentic, an organisation needs to know what its responsibility is - creating a set of crisp expectations that will determine whether its actions are reflective of and consistent with what the organisation is at its core” (ibid, p.5), assuming, of course, that these core values are both laudable and deliverable. They considered that the organisational communication function will be central to embedding notions of authenticity.

Social media's importance was emphasised by agency contributors because of the shift in the balance of power from corporations to known and unknown stakeholders. Therefore, to "boost trustworthiness and protect one's reputation in a world of democratized information access and communication" (ibid, p.5) corporations had to increase communication efforts and build dialogue and, rather inauthentically, "infiltrate opposition to anticipate critiques" (ibid, p.5). There was, however, no discussion of authenticity but a generalised view that it approximated to positive reputation-building actions.

The communication academics alone discussed definitions of authenticity and related them to existentialists (Camus, Sartre, etc) who expressed authenticity as "intrinsic motivations based on one's values" (ibid, p.7) and not a product of extrinsic forces. Thus corporations needed "an authentic core - articulated by the values of the organisation” (ibid, p.7). Corporations, they said, faced danger when changing their identity to meet public whims. Their discussion of the report expressed concerns about the introduction of 'synthetic authenticity' in order to appear authentic; and that authentic drivers may well include the neo-liberal emphasis on making profits for shareholder benefit, which Milton Friedman makes the prime responsibility of corporations. This latter concern may be a point of conflict with some stakeholders. The academics also considered "authenticity" is a continuous concept because "a corporation is always trying to be or become authentic" (ibid, p.7)

So in answer to questions as to what is "authenticity and "authentic enterprise" are, and whether the Page Society has created a $21^{\text {st }}$ century version of its founder's Principles, the answers are very unclear. There was no real discussion of authenticity in either interpersonal or corporate settings and the only definition was taken from a popular dictionary. Key writers on social identity and modernity, 
such as Bourdieu and Giddens, have been ignored. Even the extensive research and writing on reputation, [p.191] image and identity have been passed over; authenticity is surely a major component of reputation. There was no discussion of ethical concepts and their application to corporate communications and public relations, yet North America has many fine communication ethicists in close touch with practitioners. This was a missed opportunity.

As for building a $21^{\text {st }}$ century model of the Principles, the discussion was primarily on the impact of 24/7 news, social media and globalisation and the role of senior communication executives (Chief Communication Officers) in leading in the role of "conscience of the corporation”. Apart from adding emphases that the new communication methods impinge on corporations and that authenticity is an “on-going work-in-progress” (Symposium 2008, p.7), the Page Principles stand the test of time. They are moral, sensible and deliverable by all good practitioners. Tim Traverse-Healey was right to have expressed his admiration for them.

Tom Watson Bournemouth University, Bournemouth, UK

\section{References:}

Arthur W. Page Society, (2007). The authentic enterprise: Relationships, values and the evolution of corporate communications. New York: Arthur W. Page Society. Available from: http://www.awpagesociety.com/images/uploads/2007AuthenticEnterprise.pdf [Accessed 8 January 2010].

Arthur W. Page Society, (2008). Academic Symposium, May 19-21, 2008, Tuck School of Business, Dartmouth, Hanover, NH. Available from: http://www.instituteforpr.org/research single/2008 tuck school_academic symposium/ [Accessed 8 January 2010]. 